\title{
THE ROLE OF ORGANIZATIONAL VIRTUOUSNESS IN ORGANIZATIONAL CITIZENSHIP BEHAVIOR OF TEACHERS: THE TEST OF DIRECT AND INDIRECT EFFECT THROUGH JOB SATISFACTION MEDIATING
}

\author{
Sara Abedi Kooshki ${ }^{1}$, Hassanreza Zeinabadi²
}

\begin{abstract}
The aim of this study was to test the direct and indirect effect of organizational virtuousness in organizational citizenship behaviors of teachers and propose a model with a causal connection. The population consisted of all secondary school teachers of Karaj metropolitan areas where by cluster method sampling and Morgan table 403 people selected. The aim of this study is functional and in terms of methodology is survey. Standard questionnaires used to collect data and all of them had good reliability and validity. To analyze the data confirmatory factor analysis and structural equation modeling techniques used. The results showed that schools organizational virtuousness directly affect Less and non-significant on organizational citizenship behavior of teachers. The assumed test pattern suggests that organizational virtuousness with the mediation of job satisfaction can affect the behavior of teachers' organizational citizenship behavior. The findings of this study emphasis the importance of reinforcement of schools as well as teachers' job satisfaction and organizational virtuousness.
\end{abstract}

KEYWORDS: organizational virtuousness, organizational citizenship behavior, job satisfaction, teacher

JEL: I21, J28

UDC: 371.12:331.101.32

\footnotetext{
${ }^{1}$ Corresponding author, Department of Educational administration Faculty of Management Kharazmi University, Iran, e-mail: Sara.Abedi.Kooshki@gmail.com

${ }^{2}$ Department of Educational administration Faculty of Management Kharazmi University, Iran
} 


\section{Introduction}

The concept of virtue refers to the competences of the moral innate (Hessel, 2013), which through human activity contributes to improving social morality. Virtue discussed mainly in philosophy, but now, in terms of theory and application, it used in organizational researches. While early studies focused on virtue in behavior management, recent researches discuss the role of organizational virtuousness(VA) performance in other areas, such as creativity, turnover, quality, and profitability (Barclay, Markel, 2012). Organizational virtuousness with greater participation and strong relationship between people and the valuable division of resources and information is due to the increased social investment (Cameron, Dutton,Quinn, 2003). Of the positive performances of organizational virtuousness is the organization's ability to deal with the major problems faced and development of organizational virtuousness reduces the negative effects of these problems. Positive emotions and social investment created and spread by organizational virtuousness and leads to increment of individuals and organizations performance (Barkley,Markel, 2012). In addition to organizational virtuousness variable, undoubtedly the effective functioning of organizations in all circumstances is related to their work, but the effort is not only in defined boundaries (job description) and goes beyond (Garg.Rastogi, 2006). Incredible effort of staff is so important that the volume of its research, mainly on "organizational citizenship behavior(OCB)" is constantly on the rise. OCB variable has created a new wave of knowledge of the behavior of the corporate sector benefits and its importance is evident in organizational effectiveness (Oregon, 1988: Podsakoif et al., 2000).

\section{The role of schools organizational virtuousness(VA) in teachers' organizational citizenship behavior $(O C B)$}

Virtue is known as an integral element of good citizenship in communities, with the idea that it can create the field for interactions prosperity and social stability. So that it is essential to ensure the survival of the community (Cameron et al., 2004). Cameron is one of the first scholars who worked on conceptualization of organizational virtuousness. He and his colleagues believed that organizational virtuousness consisted of community activities, cultural traits or processes that enable organizational characteristics to spread and maintain virtue (Cameron et al., 2004). Accordingly, Cameron and his colleagues proposed a five-factor model of organizational virtuousness, including optimism, forgiveness, trust, compassion and integrity.

Effective schools have teachers who do their best voluntarily, non-remunerated, in addition to their role expectations and formal requirements, to assist administrators, other teachers and students and in general, school (DiPaol, Hoy, 2005). In the literature of management and organizational behavior at school these efforts benefits, are remembered as organizational citizenship behaviors.

Several studies have shown that the virtue has a critical role in creating love and empathy (Rego et al., 2011), moral strength, determination, difficulties tolerance (Seligman, 1999; Baumeiser, Exline, 2000), health, happiness, resilience in the face of adversity (Ryff,Singer, 2008; Myers, 2000). In short, ethics based on virtue is always looking for stimulation values, ideals and finding best responds to the question of what kind of organization we need to be (Chun, 2005). It is also expected that individuals who perceive their organizations as virtuous develop relational psychological contracts with the organization, thus reacting with behaviors that go beyond their in-role duties (Coyle, 2002). Feeling gratitude for working in a virtuous organization (Emmons, 2003), the individuals feel compelled to reciprocate with acts that benefit the organization and other people (Eisenberger et al., 2001) . 


\section{The mediating role of teachers 'job satisfaction}

One of the significant variables that has shown to have a high correlation with teachers' OCB is, "job satisfaction" (Garg,Rastogi, 2006; Oplatka, 2006; Bragger et al., 2005; Ngunia et al., 2006). Teachers who have high job satisfaction and organizational commitment will show more enthusiasm in organizational citizenship behavior. The evidence shows that the virtue of forgiveness is less associated with richer social relationships, higher job satisfaction, sense of power, lack of physical diagnosis, faster recovery, stress and anxiety associated disease (McCullough, 2000). Caprara et al., (2006) showed that the atmosphere of the school and many environmental variables affect job satisfaction. Evidence referred to, strengthens the assumption that organizational virtuousness, is a major determinant of job satisfaction among teachers. But according to the findings of many studies (such as Somech,DrachZahavy, 2000; LePine et al., 2002; Bajpai,Holani, 2011 and Zeinabadi, 2010) that admit the immediate effect of job satisfaction on organizational citizenship behavior, another assumption is strengthened. Accordingly, job satisfaction and organizational virtuousness is assumed as mediators effect on organizational citizenship behavior.

\section{Problem Statement}

There are few who do not believe schools and teachers not involved in the success or failure of students. Freiburg and Stein (1999) believe that school atmosphere is its heart and spirit that makes teachers and students love school and want to be part of it. Without a doubt the unique role of teacher in the education fate of students cannot be denied. But it is no secret, that not all teachers are the same in tasks and functions. Of course, teachers are successful who have certain attitudes and behaviors in their responsibilities. But the point which has remained unknown and is also the major problem of this research is how and through which factors or variables teachers' organizational citizenship behavior is affected?

This article is an answer to the challenges posed by those researchers. We agree with Wright and Goodstein's (2007) suggestion that the exploratory nature of the assessment method employed by Cameron et al. (2004) invites other researchers to employ such a measure in other contexts and in relation to other outcomes (e.g., employee loyalty; organizational commitment; and job Satisfaction). More specifically, we focus on how perceptions of organizational virtuousness predict organizational citizenship behavior (OCB), both directly and through the mediating role of affective job Satisfaction, the hypothesized model being depicted in Model 1. In other words, after achieving findings indicating role and direct and indirect importance of organizational virtuousness, the important question is does job satisfaction play a role between organizational virtuousness and organizational citizenship behavior? In this model, the effect of an exogenous latent variable (organizational virtuousness) and an indigenous latent variable (job satisfaction) are assumed positive in organizational citizenship behavior. In addition to having a direct and positive impact on organizational citizenship behavior it is assumed as an organizational virtuousness mediator on organizational citizenship behavior. 


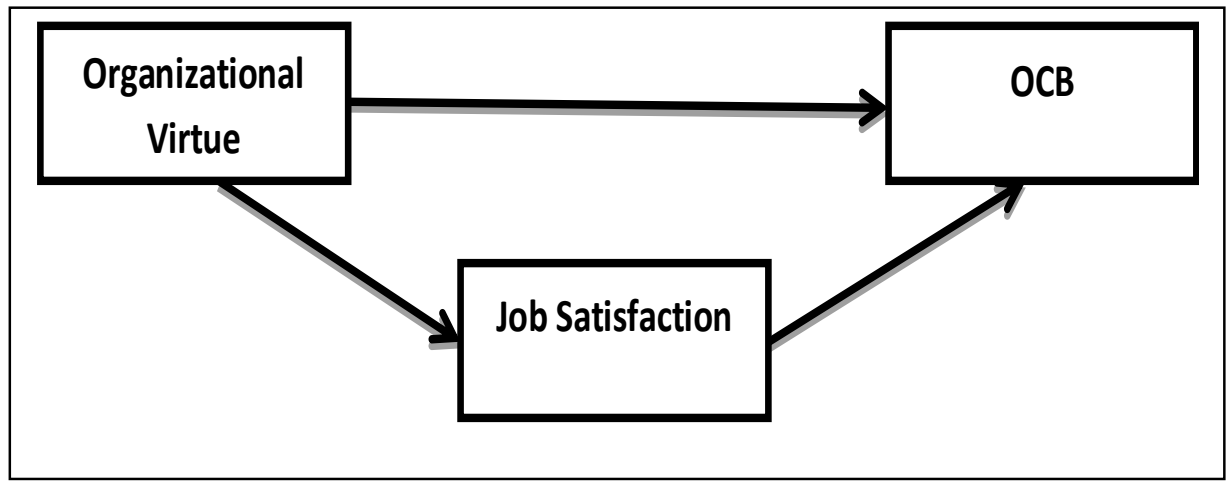

Figure 1: Hypothesized Model

Keeping this in mind, we structured the article as follows. We start by briefly discussing each construct's definition. Making use of a double-source method for collecting data on dependent and independent variables, we hope to contribute to a better understanding of what is surely a central challenge for many contemporary organizations and their managers: to identify forms of using and developing their human capital in a way that is mutually beneficial for themselves and their employees.

\section{Objectives and hypotheses}

The aim of this study was to test the direct and indirect effect of (through the intermediary of job satisfaction) organizational virtuousness in organizational citizenship behaviors of teachers and schools and propose a casual model. Given the pattern of research, this research has been to determine whether the data collected have the direct and indirect effects or not? And also whether it can be as organizational virtuousness through the impact on organizational citizenship behavior suggested teachers? Perhaps the ideal goal of this research was to improve teachers' organizational citizenship behavior by increasing job satisfaction and stimulating policy makers and researchers to pay more attention to the importance of organizational virtuousness in schools. To achieve these goals, the following hypotheses were tested:

- There is a significant correlation between organizational virtuousness, job satisfaction and organizational citizenship behavior of teachers.

- Organizational virtuousness has a significant direct effect on organizational citizenship behavior.

- Organizational virtuousness has a direct and significant impact on job satisfaction.

- Job satisfaction has a significant direct effect on organizational citizenship behavior.

- Organizational virtuousness has a significant indirect effect on organizational citizenship behavior.

- The given pattern is a good fit with the data. 


\section{Methodology}

\section{Method of the study}

The present study is "practical" in terms of purpose and "descriptive" in terms of method of data collection. Given that in this study the relations between the two and multivariate relationships and casual relationships (of causal modeling) between variables (in a given model) were considered, therefore it can be said that the method of the present study is a description of the correlation and bivariate causal modeling.

\section{Population}

The sample consisted of 403 teachers (208 men and 195 women) from public high school of four areas of Karaj metropolitan.

\section{Data Analysis Method}

The data was analyzed using LISREL 8.80 software. confirmatory factor analysis(CFA) is the basis of the measurement model in full structural equation modeling (SEM) and can be estimated using SEM software. LISREL is the most user-friendly. LISREL can read data files generated by a variety of different software packages and can estimate models by simply drawing a path diagram.

To assess the validity of the constructions "Confirmatory factor analysis" and to answer research questions "path analysis" (with respect to assumptions) used. That is means Following the completeion of validityand reliability analysis on the scales of research model; structural equation model (SEM) will be implemented in order to analyse the interaction among variables, identify direct and indirect effects on variables and test hypothesis and research model. SEM is a comprehensive statistical technique to test causal relationships among latent and observed variables (Y1lmaz, 2004). Structural model means structural equations that define the causal relationships among latent endogeneous and exogeneous variables and identify explained and unexplained variance. Measurement model is tested through confirmatory factor analysis, while structural model is tested through path analysys(Yilmaz, Çelik, 2009). Absolute fit indices determine how well an priori model fits the sample data (McDonald, Ho, 2002) and demonstrates which proposed model has the most superior fit. These measures provide the most fundamental indication of how well the proposed theory fits the data. Unlike incremental fit indices, their calculation does not rely on comparison with a baseline model but is instead a measure of how well the model fits in comparison to no model at all (Joreskog,Sorbom, 1993). Included in this category are the:

Chi-Squared test (X2): The Chi-Square value is the traditional measure for evaluating overall model fit and, 'assesses the magnitude of discrepancy between the sample and fitted covariances matrices' (Hu,Bentler, 1999).

Comparative fit index (CFI): this statistic assumes that all latent variables are uncorrelated (null/independence model) and compares the sample covariance matrix with this null model (Bentler, 1990). 
Goodness of fit (GFI) and the adjusted goodness of fit (AGFI): calculates the proportion of variance that is accounted for by the estimated population covariance (Tabachnick, Fidell, 2007).

Normed fit index (NFI): This statistic assesses the model by comparing the $\chi 2$ value of the model to the $\chi 2$ of the null model(Bentler, Bonnet,1980).

Root mean square error of approximation (RMSEA): The RMSEA tells us how well the model, with unknown but optimally chosen parameter estimates would fit the populations covariance matrix (Byrne, 1998).

It is worth noting that in both the CFA and in the process of examining how a given model fit indices Chi-Squared test $\left(\mathrm{X}^{2}\right)$ (as long as a significant loss), fitting comparison (CFI), between 0.9 and 1(Hu, Bentler, 1999), goodness of fit (GFI), between 0.9 to 1 (Miles,Shevlin,1998), adaptive goodness of fit (AGFI) ,between 0.9 to 1(Tabachnick, Fidell, 2007) and mean square error of approximation (RMSEA), less than 0.08 (Steiger,Lind, 1980) used. For a closer look at the pattern additional measures including the normal fit index (NFI), between 0.9 and 1(Bentler, Bonnet,1980) and incremental fit index (IFI), between 0.9 and 1 (Kline, 2011) used.

\section{Research tools}

Data was collected using 3 standard questionnaires. To measure organizational virtuousness Cameron et al questionnaire with 15 items (2004) designed based on 5 dimensions of organizational optimism, organizational trust, organizational compassion, organizational solidarity, organizational mercy was used. Also, the job satisfaction questionnaire with 20 items of Minnesota (MSQ), developed by Weiss et al.,(1967) was used to measure internal satisfaction, external satisfaction and overall satisfaction. OCB of teachers was measured using Dipaloa's questionnaire of 15 items (2004). In this study, teachers were asked to describe the statements during the five-point scale of Likerd grading (from very low $=1$ to very high $=5$ ). The reliability of the questionnaire was reported $0.92,0.92$ and 0.85 respectively using the Cronbach's alpha for organizational virtuousness, job satisfaction and organizational citizenship behavior (by the removal of two items).

To assess the validity and confirmatory factor analysis was conducted and it was found that scales with high throughput and a good fit measure organizational virtuousness, job satisfaction and organizational citizenship behavior variables (Table 1).

Table 1: parameters for measuring variables of $O \mathrm{~V}$, job satisfaction and $O C B$ in $C F A$

\begin{tabular}{|c|c|c|c|c|}
\hline \multirow{7}{*}{$\begin{array}{l}\text { Organizational } \\
\text { Virtuousness }\end{array}$} & Subscales & $\begin{array}{c}\text { Standard } \\
\text { Parameter of } \\
\beta\end{array}$ & Scale Error & Quantity of $t$ \\
\hline & Organizational optimism & 0.65 & 0.46 & $10.46^{*}$ \\
\hline & Organizational trust & 0.82 & 0.32 & $15.89^{*}$ \\
\hline & $\begin{array}{c}\text { Organizational } \\
\text { compassion }\end{array}$ & 0.96 & 0.07 & $15.58^{*}$ \\
\hline & Organizational integrity & 0.98 & 0.04 & $16.48^{*}$ \\
\hline & $\begin{array}{c}\text { Organizational } \\
\text { forgiveness }\end{array}$ & 0.83 & 0.34 & $15.46^{*}$ \\
\hline & $\begin{array}{l}\text { Fitting indicators : } \\
\qquad \mathrm{X}^{2}=246,\left(\mathrm{X}^{2} / \mathrm{df}\right)=3.12\end{array}$ & $\begin{aligned}\mathrm{RMSEA}) & =0.0 \\
(\mathrm{CFI}) & =0.9\end{aligned}$ & $\mathrm{GFI})=0.95$ & $\mathrm{HFI})=0.93$ \\
\hline
\end{tabular}




\begin{tabular}{|c|c|c|c|c|}
\hline \multirow{4}{*}{ Job Satisfaction } & Internal satisfaction & 0.88 & 0.19 & $12.9^{*}$ \\
\hline & External satisfaction & 1.11 & -0.25 & $16.5^{*}$ \\
\hline & Overall satisfaction & 0.91 & 0.43 & $5.89^{*}$ \\
\hline & \multicolumn{4}{|c|}{$\begin{array}{l}\text { Fitting indicators : } \\
\qquad \mathrm{X}^{2}=575,\left(\mathrm{X}^{2} / \mathrm{df}\right)=3.47,(\mathrm{RMSEA})=0.07,(\mathrm{GFI})=0.95,(\mathrm{AGFI})=0.92, \\
(\mathrm{CFI})=0.97\end{array}$} \\
\hline \multirow{14}{*}{ OCB } & Q1 & 0.60 & 0.10 & $8.63^{*}$ \\
\hline & Q3 & 0.73 & 0.13 & $11.24^{\text {絭 }}$ \\
\hline & Q4 & 0.77 & 0.08 & $12.12^{\text {䊑 }}$ \\
\hline & Q5 & 0.79 & 0.10 & $12.57^{\text {불 }}$ \\
\hline & Q6 & 0.79 & 0.10 & $12.51^{\text {数 }}$ \\
\hline & Q7 & 0.73 & 0.13 & 11.14 粪 \\
\hline & Q8 & 0.80 & 0.09 & $12.71^{\text {絭 }}$ \\
\hline & Q9 & 0.86 & 0.08 & 14.39 \% \\
\hline & Q10 & 0.89 & 0.08 & $15.15^{\text {*ै }}$ \\
\hline & Q11 & 0.81 & 0.09 & $12.9^{\text {粦 }}$ \\
\hline & Q12 & 0.78 & 0.17 & $9.12^{\text {絭 }}$ \\
\hline & Q14 & $\overline{0.86}$ & 0.08 & $14.26^{\text {䊑 }}$ \\
\hline & Q15 & 0.85 & 0.10 & $14.09^{\text {* }}$ \\
\hline & \multicolumn{4}{|c|}{$\begin{array}{l}\text { Fitting indicators : } \\
\qquad \begin{array}{l}\mathrm{X}^{2}=80,\left(\mathrm{X}^{2} / \mathrm{df}\right)=3.48,(\mathrm{RMSEA})=0.06,(\mathrm{GFI})=0.97,(\mathrm{AGFI})=0.94, \\
(\mathrm{CFI})=0.96\end{array}\end{array}$} \\
\hline \multicolumn{5}{|l|}{$\mathrm{P}<0.05^{*}$} \\
\hline
\end{tabular}

As seen in Table 1, one of the indicators is not desirable. But it should be noted that: First, there is no convergence among scholars about the optimal value of the indices; for instance, some believe even very large amount of 5 degrees of $\left(\mathrm{X}^{2} / \mathrm{df}\right)$ freedom is fit (Wheaton, 1977). Second, when the square index $\left(\mathrm{X}^{2}\right)$ becomes significant for reasons such as an increase in the sample size, attention is paid to alternative indices. Clearly rest of the indices are at an acceptable level so standardized coefficients and indicators are fitted showing the validity of these tools and the perfect fit of the measured variables with the data.

\section{Findings}

Table 2 shows the variables described using the mean and standard deviation.

Table 2: Statistical description of variables

\begin{tabular}{||ccc|}
\hline Latent Variables & Mean & Standard Deviation \\
\hline $\begin{array}{c}\text { Organizational } \\
\text { Virtuousness }\end{array}$ & 3.59 & 0.74 \\
\hline Job Satisfaction & 3.66 & 0.70 \\
\hline OCB & 3.42 & 0.60 \\
\hline
\end{tabular}

In the first hypothesis test, Pearson correlation coefficient was calculated between the variables listed in Table 3 respectively. 
Table 3: Correlation coefficients between variables

\begin{tabular}{||cccc||}
\hline Latent Variables & Organizational Virtuousness & Job Satisfaction & OCB \\
\hline Organizational Virtuousness & 1 & & \\
\hline Job Satisfaction & 0.72 & 1 & \\
\hline OCB & 0.48 & 0.63 & 1 \\
\hline
\end{tabular}

As Table 2 shows, there is a significant correlation between all the variables at 0.01 . The highest coefficient of correlation was between organizational virtuousness ( $r=0.72)$ and job satisfaction of teachers. After that OCB has the highest correlation with job satisfaction $(\mathrm{r}=0.63)$. The organizational virtuousness has the lowest correlation with organizational citizenship behavior $(\mathrm{r}=0.48)$. The first hypothesis test conclusion is that there is a significant correlation between the variables.

Before examining the hypotheses, to inform them of the presence of exogenous and endogenous variable in the model, as a first step, given fitted model offered. Model 2 is achieved from the relationship between latent exogenous variable (organizational virtuousness) with an endogenous latent variable (OCB) and endogenous latent variable intermediary other (job satisfaction).

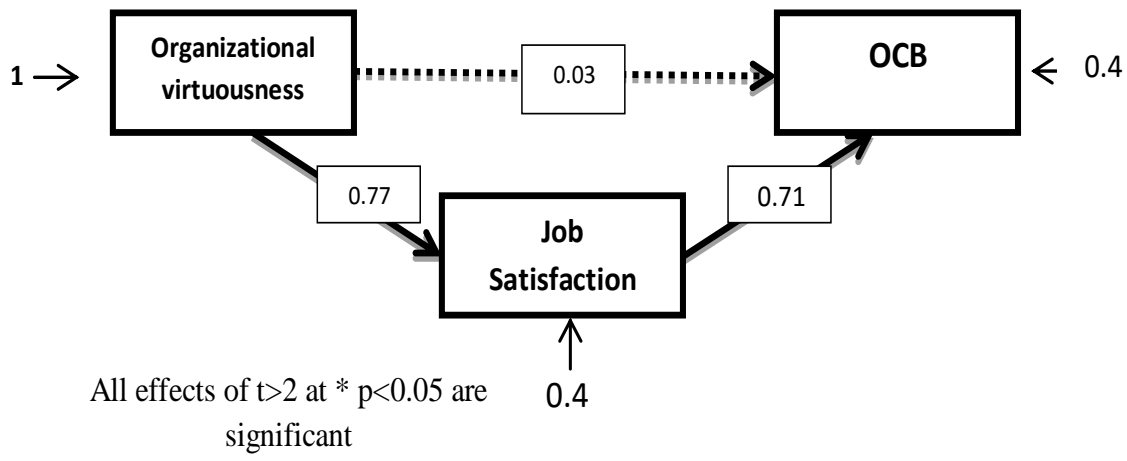

Figure 2: Assumed model of study after fit

In the test of given model, the direct and indirect effects of the parameters in Table 3 have been examined and reported.

Table 3:Direct and indirect effects if parameters in a given pattern after fit

\begin{tabular}{ccccc} 
& Effects & $\begin{array}{c}\text { Standard } \\
\text { Parameter of } \beta\end{array}$ & $\begin{array}{c}\text { Standard } \\
\text { deviation }\end{array}$ & $\mathrm{T}$ \\
\hline \multirow{3}{*}{ Direct } & $\begin{array}{c}\text { Organizational } \\
\text { virtuousness on OCB }\end{array}$ & 0.03 & 0.07 & $0.38^{\text {n.s }}$ \\
\cline { 2 - 5 } & $\begin{array}{c}\text { Organizational } \\
\text { virtuousness on Job } \\
\text { Satisfaction }\end{array}$ & 0.77 & 0.07 & $10.82^{*}$ \\
\cline { 2 - 5 } Indirect & Job Satisfaction on OCB & 0.71 & 0.1 & $6.99^{*}$ \\
\hline $\begin{array}{c}\text { Organizational } \\
\text { virtuousness on OCB by } \\
\text { job satisfaction mediatory }\end{array}$ & 0.57 & 0.06 & $9.04^{*}$ \\
& & & & $\mathrm{P}<0.05$
\end{tabular}


Looking at the Table 3 and test of second hypothesis, we find that, a standard parameter coefficient $(\beta=0.03)$ shows significance between organizational virtuousness and organizational citizenship behavior and $\mathrm{t}$ value at 0.38 is evidence of direct influence; also OCB is insignificant on organizational virtuousness. Therefore, the direct effects of exogenous variables are statistically insignificant. Test of third hypothesis suggests that the standard parameter coefficient of $(\beta=0.77)$ and $t$ at 10.82 are evidences of the direct and significant impact on job satisfaction to organizational virtuousness. The fourth hypothesis testing also showed that satisfaction with the standard parameter coefficient of $(\beta=0.71)$ had a direct impact on organizational citizenship behavior of teachers. The study of this effect at $t$ value of 6.99 indicated that the effect is statistically significant. The fifth hypothesis suggests that organizational virtuousness (with the mediation of job satisfaction) with standard parameter coefficient $(\beta=0.57)$ have an indirect effect on organizational citizenship behavior of teachers. In considering the significance of this work, the value of t equal to 9.04, suggests that this effect is statistically significant. To test the sixth hypothesis of goodness of fit index pattern is analyzed and reported in Table 4.

Table 4: Indicators of goodness of fit of the model

\begin{tabular}{|cc||}
\hline Goodness of fit indices & Values of Indices \\
\hline Square & 4071 \\
\hline Degrees of freedom $\left(\mathrm{X}^{2}\right)$ & 1077 \\
\hline $\begin{array}{c}\text { Square to the degrees of } \\
\text { freedom }\left(\mathrm{X}^{2} / \mathrm{df}\right)\end{array}$ & 3.7 \\
\hline $\begin{array}{c}\text { Root mean square error of } \\
\text { approximation (RMSEA) }\end{array}$ & 0.09 \\
\hline Goodness of fit index (GFI) & 0.93 \\
\hline $\begin{array}{c}\text { Modified goodness of fit } \\
\text { index (AGFI) }\end{array}$ & 0.90 \\
\hline The normal fit index (NFI) & 0.91 \\
\hline Comparative fit index (CFI) & 0.93 \\
\hline Incremental fit index (IFI) & 0.93 \\
\hline
\end{tabular}

As seen in Table 4, ( $\left.\mathrm{X}^{2} / \mathrm{df}\right)$ and (RMSEA) is not desirable. But it should be noted that: First, there is no convergence among scholars about the optimal value of this indexes for instance, some believe even very large amount of 5 degrees of freedom (X2/df) are fit (Wheaton, 1977). Second, when the square index of $\left(\mathrm{X}^{2}\right)$ inter alia becomes statistically significant by increasing the sample size, attention is paid to alternative indices. Clearly rest of these indices are at an acceptable level except RMSEA! GFI to 0.93, AGFI to 0.90, NFI equal to 0.91 , CFI and IFI equal to 0.93 are all higher than the 0.9 and at an acceptable level.

There fore and Due to this one of the paths (a direct effect organizational citizenship behavior on organizational virtuousness) is not significant, can't said be given an appropriate model and complete model to explain the organizational citizenship behavior. In this cases, can be "modify " model (Schumacker \& Lomax, 2004). they know the Remove nonsignificant paths the proper way. On the basis in this review by removing the direct effect of organizational citizenship behavior on organizational virtuousness, Amended and re-fitted to a given pattern that results report in table 5 . 
Table 5: Direct and indirect effects and Indicators of goodness fit of the final model

\begin{tabular}{|c|c|c|c|c|}
\hline & Effects & $\begin{array}{c}\text { Standard } \\
\text { Parameter of } \beta\end{array}$ & $\begin{array}{l}\text { Standard } \\
\text { deviation }\end{array}$ & $\mathrm{T}$ \\
\hline \multirow{3}{*}{ Direct } & $\begin{array}{c}\text { Organizational } \\
\text { virtuousness on OCB }\end{array}$ & \multicolumn{3}{|c|}{ Removed } \\
\hline & $\begin{array}{c}\text { Organizational } \\
\text { virtuousness on Job } \\
\text { Satisfaction }\end{array}$ & 0.80 & 0.06 & $10.89^{*}$ \\
\hline & Job Satisfaction on OCB & 0.76 & 0.09 & $8.87^{*}$ \\
\hline Indirect & $\begin{array}{l}\text { Organizational } \\
\text { virtuousness on OCB by } \\
\text { job satisfaction mediatory }\end{array}$ & 0.60 & 0.05 & $9.91^{*}$ \\
\hline $\begin{array}{l}\text { Fitting ind } \\
\qquad\left(\mathrm{X}^{2} / \mathrm{d}\right.\end{array}$ & , $($ RMSEA $)=0.07,(\mathrm{GFI})=0$ & $\begin{array}{l}=0.94 \\
,(\mathrm{AGFI})=0.91\end{array}$ & $\mathrm{FI})=0.9$ & 98 \\
\hline
\end{tabular}

As seen in Table 5, these indices are at an acceptable level. On the basis of this result is sixth hypothesis, the given pattern, can be a good fit to the data and can be proposed as organizational virtuousness through the impact on organizational citizenship behavior of teachers.

\section{Discussion}

The aim of this study was to test the direct and indirect effects of (through the intermediary of job satisfaction) organizational virtuousness in organizational citizenship behaviors of teachers and schools. Results showed verification of all hypotheses, but the second one. In the first hypothesis testing, correlation coefficients between the variables of the study showed that there is a significant correlation between all the variables at 0.01 . The second hypothesis test results show that the organizational virtuousness has a direct, low and non-significant impact on organizational citizenship behavior of teachers. However, in this study, the correlation between organizational virtuousness and organizational citizenship behaviors of teachers $(r=0.48)$ is reported significant, but direct research to examine this relationship is not seen to be comparable, but it is not a significant direct effect, unlike Bogler and Samech (2009) and Oplatka (2009) it is more or less the same individual variables of organizational virtuousness on organizational citizenship behavior in non-educational organizations. In fact, teachers with good ethics, trust, forgiveness, honesty, compassion and optimism in the school environment are certainly evidences of organizational behavior, but whether teachers immediately and directly impact on organizational citizenship behavior.. In contrast agents explained this result with similar research in the past, it should be stated that, first, they are different organizational characteristics, secondly it can be due to the culture of the countries where the research is carried out.

The third hypothesis testing showed that organizational virtuousness has a strong and significant impact on teachers' job satisfaction. This result is consistent with previous research results, such as Capra (2006), Fabian (2012), Fernando, Almeida (2012). The fourth hypothesis test results showed that job satisfaction has a direct, significant and positive 
impact on organizational citizenship behavior of teachers. Somech et al.,(2000), Lepine (2002), Tsui et al., (2007), Bowling,Hamond (2008), Bajpai,Holani (2011), and Zeinabadi (2009 and 2010) showed that job satisfaction has (direct or indirect) impact on their organizational citizenship behavior in several ways in several ways. The results indicate that job satisfaction makes organizational citizenship behavior through helping other teachers to help students in the classroom and outside the classroom, the school in general, parents and contribute to personal growth done (Zeinabadi, 2010).

Organizational virtuousness has an indirect effect on organizational citizenship behavior with job satisfaction mediating which was tested in the fifth hypothesis. The test results demonstrate that significant effect of the relationship was indirect. Therefore, we can conclude that organizational virtuousnesse through job satisfaction has a positive indirect effect on organizational citizenship behavior of teachers. When organizational virtuousnesses and virtuous behavior-oriented development which include the development of optimism, confidence, compassion, solidarity and forgiveness in the organization, the human resources greatly enhances retention and satisfaction, because the school or organization with virtuousnesses, habits, attitudes and actions leads to the production of social and individual happiness and will introduce these to employees with gratitude and when teachers are happy in school it eventually leads to such complacency, leading to the behaviors that they referred to the organizational citizenship behaviors (Varmazyar, 2013).

Sixth hypothesis test results showed that the model fit the supposed goodness of fit model with the data of a given pattern, and pattern can be given as a model for organizational virtuousnesse effect on organizational citizenship behavior of teachers.

According to what has been through, the great impact of organizational citizenship behavior is considered the most important and most logical explanation about its importance of (Smith et al., 1983; Padsakof et al., 2000; Dipaola, Hui, 2005). Therefore, in the community of teachers, voluntary behavior at school can help teachers to help students and the school in general as well as contributing to personal growth, classroom, administrators and even parents. Organizational virtuousnesses with moral character properties are recognized as high performance organizations. As schools of higher corporate virtues are certainly, in this behavior that it will be known as organizational citizenship behavior, but as we have seen, for most of these behaviors, teachers in schools with high organizational virtuousnesses, working they must also have high job satisfaction. However, for growth of such attitudes and feelings, teachers who are working at schools with high virtue must have high job satisfaction; that is because with such views and feelings, they will truly and deeply love the school and its environment and take on their duties better than ever or even more than they are expected to.

\section{Conclusion}

The world has never experienced such magnitude of economic depression as the one it currently faces. Thus, at a time like this there is usually the urge on the part of organizations and their members to indulge in unethical practices as a surviving strategy. Fortunate enough, positive organizational behavior such as virtuousness and individual employee optimism have proved to be what organizations really needed to survive with a in a dilapidated business environment. The main thrust of positive psychology has been to catalyze a change in the focus of psychology from pre-occupation only with repairing the worst things in life to also building positive qualities (Seligman, Csiksentmihalyi, 2000). Ignoring the positive aspect of work is inappropriate if we must appreciate the meaning and effects of working (Turner et 
al.,2002). It is against this background that studies on positive psychology such as the present is not only timely, but necessary. Accordingly, those working in education and training managers as the most important factor of social, economic and cultural development to achieve better and higher education, should strengthen the mechanisms of organizational virtuousness and provide job satisfaction of teachers in schools. Finally, it is suggested that in future studies, the researchers compare the test pattern, different levels of education in schools, by age, gender, education, job experience and organizational level of teachers or add some other variables for which there is no justification.

\section{References}

[1] Bajpai. N, Holani. U. (2011) "Organizational Citizenship Behavior in Public and Private Sector and Its Impact on Job Satisfaction: A Comparative Study in Indian Perspective". International Journal of Business and Management, Vol 6, No 1

[2] Baumeister, R.,Exline, J. (2000), "Self Control, Morality and Human Strength"Journal of Social and Clinical Psychology, N 19, PP: 29-42.

[3] Barclay, L. A.,Markel, K.S. (2012). "Virtue theory and organizations: considering persons with disabilities". Journal of Managerial Psychology, 27 (4): 330 - 346.

[4] Bentler, P.M. (1990), "Comparative Fit Indexes in Structural Models," Psychological Bulletin, 107 (2), 238-46.

[5] Bentler, P.M., Bonnet, D.C. (1980), "Significance Tests and Goodness of Fit in the Analysis of Covariance Structures," Psychological Bulletin, 88 (3), 588-606.

[6] Bragger J., Rodriguez-Srednicki O., Kutcher E., Indovino L., Rosner E. (2005). "Workfamily conflict, work-family culture, and organizational citizenship behavior among teachers". Journal of Business and Psychology, No.20, pp 303-324.

[7] Bogler, R.,Somech. A. (2009). "Organizational citizenship behavior in school: How does it relate to participation in decision making?". Journal of educational Administration, 43 (5), PP.420-438.

[8] Bowling. A.,Homond. (2008). "Quantitative social sciences: The survey". In Bowing. A., \& Ebrahim. S. (Eds.), Handbook of health research methods: Investigation, measurement and analysis, (pp. 190-214) Maidenhead, England: Open University Press.

[9] Byrne, B.M. (1998), Structural Equation Modeling with LISREL, PRELIS and SIMPLIS: Basic Concepts, Applications and Programming. Mahwah, New Jersey: Lawrence Erlbaum Associates.

[10] Chun, R. (2005). "Ethical Character and Virtue of Organization: An Empirical Assessment and Strategic Implications". Journal of Business Ethics, 57 (3): 269-284.

[11] Cameron, K., Dutton, J., Quinn, R. (2003). "Positive Organizational Scholarship", San Francisco: Berrett Koeheler, 48-65.

[12] Cameron. K.S., Bright. D.,Caza. A. (2004). "Exploring the relationship between organizational virtuousness and performance". American behavioral scientist, Vol. 47, No. 6: 1-24.

[13] Caprara GV, Barbaranelli, C., Malone, P.,Steca P. (2006). "Teachers 'self-efficacy beliefs as determinants of job Satisfaction and students' academic achievement" .Journal of School Psychology, $\neg$ 44, PP. 473-490. 
[14] Coyle-Shapiro, J. (2002). A Psychological Perspective on Organizational Citizenship Behavior. Journal of Organizational Behavior, 23(8), 927-946.

[15] DiPaola, M., Tarter, C.,Hoy W. K. (2004). "Measuring organizational citizenship in schools: The OCB Scale". In Wayne K. Hoy \& Cecil Miskel (Eds.) Leadership and Reform in American Public Schools. Greenwich, CT: Information Age.

[16] DiPaola, M. F.,Hoy, W. K. (2005). "School characteristics that foster organizational citizenship behavior". Journal of School Leadership, 15, pp. 308-326.

[17] Emmons, R. A. (2003). Acts of Gratitude in Organizations in K. S. Cameron, J., Dutton, E., \& Quinn, R. E. (eds.), Positive Organizational Scholarship. BerrettKoehler, San Francisco, 81-93.

[18] Eisenberger, R., Armeli, S., Rexwinkel, B., Lynch, P. D.,Rhoades, L. (2001). Reciprocation of Perceived Organizational Support. Journal of Applied Psychology, 86(1), 42-51.

[19] Fabian, O. (2012). "Are good morals often reciprocated: perceptions of organizational virtuousness and optimism as predictors of work engagement?". Asian journal of social science and humanities, vol. 1, No.3: 188-198.

[20] Fernando. M.,Almeida. S. (2012). "The organizational virtuousness of strategic corporate social responsibility: A case study of the Sri Lankan Family owned enterprise MAS holding". European management journal, 30: 564-576.

[21] Freiberg, H. J.,Stein, T. A. (1999). "Measuring, improving and sustaining healthy learning environments". in: Freiberg, HJ (ed. School Climate: Measuring, Improving and Sustaining Healthy Learning Environments. Philadelphia, PA: Falmer Press, p. 11.

[22] Garg,P.,Rastigi,R. (2006). "Climate profile and OCBs of teachers in public and private schools of India". International Journal of Educational Management, 20 (7), 529-54.

[23] Hessel, I. (2013). "Developing A Virtuos Aspect of Leadership: A Case Study of the Virtuous Projects Approach to Leadership Development". Master Thesis in Education, Department of Educational Research, University of Oslo.

[24] Hu, L.T.,Bentler, P.M. (1999). "Cutoff Criteria for Fit Indexes in Covariance Structure Analysis: Conventional Criteria Versus New Alternatives," Structural Equation Modeling, 6 (1), 1-55.

[25] Jöreskog, K.,Sörbom, D. (1993). LISREL 8: Structural Equation Modeling with the SIMPLIS Command Language. Chicago, IL: Scientific Software International Inc.

[26] Kline, R.B. (2011). Principles and Practice of Structural Equation Modeling (2nd Edition ed.). New York: The Guilford Press.

[27] LePine, J.A., Erez, A.,Johnson, D.E. (2002). "The Nature and Dimensionality of Organizational Citizenship Behavior: A Critical Review and Meta-analysis". Journal of Applied Psychology, 87, pp. 52-65.

[28] McDonald, R.P., Ho, M.-H.R. (2002). "Principles and Practice in Reporting Statistical Equation Analyses," Psychological Methods, 7 (1), 64-82.

[29] Miles, J.,Shevlin, M. (1998). "Effects of sample size, model specification and factor loadings on the GFI in confirmatory factor analysis," Personality and Individual Differences, 25, 85-90.

[30] McCullough, M. E. (2000). "Forgivenss as human strenght: Theory, measurement, and links to well-being". Journal of Social and Clinical Psychology, 19, 43-55. 
[31] Myers, D. G. (2000). "The Funds, Friends, and Faith of Happy People". American Psychologist, 55, pp. 56-67.

[32] Ngunia, S., Sleegers, P.,Denessen, E. (2006). Transformational and transactional leadership effects on teachers' job satisfaction, organizational commitment, and organizational citizenship behavior.

[33] Organ, D. W. (1988). "Organizational Citizenship Behavior: the Good Soldier Syndrome". Leaxington, MA: Lexington Books.

[34] Oplatka, I. (2006). "Going Beyond Role Expectations: Toward an Understanding of the Determinants and Components of Teacher Organizational Citizenship Behavior". Educational Administration Quarterly, 42 (3), PP. 385-423.

[35] Oplatka, I. (2009). "Organizational citizenship behavior in teaching: The consequences for teachers, pupils, and the school". International Journal of Educational Management, 23 (5), 379-389.

[36] Podsakoff P, M., MacKenzie, SB, Paine, JB,Bachrach, DG (2000). "Organizational Citizenship Behaviors: A Critical Review of the Theoretical and Empirical Literature and Suggestions for Future Research". Journal of Management, 26: 513- 563.

[37] Rego. A., Riberiro. N., Cunha. M.P., Jesunio. J.C. (2011). "How happiness mediates the organizational virtuousness and affective commitment relationship". Journal of business research, 64: 524- 532 .

[38] Ryff, C.,Singer, B. (2008). "The Contours of Positive Human Health", Psychological Inquiry, N 9, PP: 1-28.

[39] Seligman, M. (1999). "The President's Address". American Psychologist, 54, pp. 559562.

[40] Steiger, J. H.,Lind, J. (1980), "Statistically-based tests for the number of common factors," Paper presented at the Annual Spring Meeting of the Psychometric Society, Iowa City.

[41] Smith, C.A., Organ, D.W.,Near, J.P. (1983). "Organizational citizenship behavior: Its nature and antecedents". Journal of Applied Psychology, 68: 653 - 663.

[42] Somech, A.,Drach-Zahavy, A. (2000). "Understanding extra-role behavior in schools: The relationships between job satisfaction, sense of efficacy, and teachers extra-role behavior". Teaching and Teacher Education, 16 (5-6), 649-659.

[43] Tabachnick, B.G.,Fidell, L.S. (2007). Using Multivariate Statistics (5th ed.). New York: Allyn and Bacon.

[44] Tsui, A. S. \& Kifadkar, S. S. (2007). "Cross-National, Cross - Cultural Organizational Behavior Researc: Advances, Gaps, and Recommendations" .Journal of management, V.33, N.3: 426-478.

[45] Varmzyar, R., Morad A. (2013). Organizational health role in academic achievement in chemistry mediated efficacy, job satisfaction and organizational citizenship behavior secondary school teachers, educational research master's thesis, University of Tehran Khwarizmi(in Persian).

[46] Weiss, DJ, Dawis, RV England, GW,Lofquist, LH (1967). "Manual for the Minnesota Satisfaction Questionnaire". Minneapolis: University of Minnesota.

[47] Wheaton, JB, Muthen, B., Alwin, DF,Summers, G. (1977). "Assessing Reliability and Stability in Panel Models". Sociological Methodology, 8 (1), 84-136. 
[48] Wright, T., Goodstein, J.( 2007), 'Character is not "Dead"' in Management Research: A Review of Individual Character and Organizational-Level Virtue', Journal of Management 33(6), 928-958.

[49] Yilmaz, V. (2004). LISREL ile Yapisal Esitlik Modelleri: Tüketici Sikâyetlerine Uyg ulanmasi. Anadolu Üniversitesi Sosyal Bilimler Dergisi, 4(1): 77-90.

[50] Yilmaz, V., Çelik, E.H. (2009). LISREL ile Yapisal Esitlik Modellemesi-1. Istanbul: Pegem Akademi.

[51]Zeinabadi, Hassan R. (2010). Transformational leaders, school managers and administrators woman man, Women in Development \& Politics (of women), 8 (2): 141-115.

[52]Zeinabadi, Hassan R. (2009). Organizational citizenship behavior, job satisfaction and commitment to the school: Is there a significant difference between male and female teachers? Females, 3 (1):pages 27-4.

\section{Article history:}

- $\quad$ Received 25 March 2016

- $\quad$ Accepted 4 May 2016 